\title{
How Not to Run Reseurch Councils (Indian style)
}

THE sad case of Dr V. H. Shah's suicide in New Delhi last week is a telling symptom of the malaise which afflicts publicly supported research in India (see page 130). Whether Dr Shah is right or wrong in suggesting that he should have been preferred to the one of the two men recently appointed to the two senior posts in agronomy at the Indian Agricultural Research Institute and the Indian Council for Agricutural Research is beside the point. The truth is that these organizations, like many other of the research organizations supported by the Government of India, are too rigid, too hierarchical and too directly exposed to political pressure and personal logrolling. In one respect, at least, Dr Shah's suicide has been counter-productive in that it has exposed the agricultural research organizations more directly to political pressure from outside, which is why the Minister of Agriculture, Mr Fakhruddin Ali Ahmed, is to be congratulated for having denied a parliamentary inquiry. It is to be hoped that his resolution will survive the next few weeks. But although there is some hope that the internal review of the Indian Council for Agricultural Research now under way may be able to remedy some of the causes of those among Dr Shah's complaints which are legitimate, the chance is very small that the outcome will be a sufficiently radical transformation of the present state of affairs.

Nobody will dispute that younger scientists in Indian laboratories are frequently kept under the thumbs of their more senior colleagues, but it is unrealistic to single out one research organization for blame or even to suppose that the hierarchy can become less cramping until scientists themselves set much less store than they do at present on the acquisition of formal qualifications for promotion-not merely university degrees and diplomas but also the tally of published articles in the literature. (Absurdly, in some circles at least, one article in Nature is as good for a man's advancement as half-a-dozen in the Indian scientific press.) The need is somehow to create within the organizations such as the Indian Council for Scientific and Industrial Research and the Indian Council for Agricultural Research a system of organizations which is flexible enough to allow people at all levels to contribute towards what should be a common objective. If this should entail that relatively junior scientists should frequently be seen to be more expert, or more knowledgeable, than their betters, that is merely a sign of what creative research is like.

Outside India but also at places such as the Bhabha Atomic Research Centre and at internationally reputed centres such as the Tata Institute for Fundamental Research, laboratories are increasingly populated by bright young men and women who are expected and are alarmingly able to hold their own intellectually with the greybeards. In circumstances like these, the authority of senior people derives as much from their capacity to listen well as from their own current competence in research.
Leadership is as important as innovation, and a laboratory's success depends largely on the skill with which its head can act as an impresario for his younger colleagues. Although in the past few years there have been welcome signs that this principle is gaining ground, at the present rate a long time will pass before scientists at all levels in government research will be as free as they would like.

Change could be quicker if the Government of India were less directly concerned with the administration of the research councils. As things are, the councils responsible for scientific and industrial research, agricultural research and medical research are presided over by the Cabinet Minister from whose budget funds are provided, and this personage-with interests and ambitions usually quite outside research - is formally responsible for all appointments. The result is that there are perennial arguments about the propriety of appointments, while the rates at which scientific workers are paid are closely linked with the antiquated pay scales of the Indian Civil Service as a whole. Inevitably, quite minor grievances become publicly political issues, and are not dealt with where they should be dealt with-internally. Worse still, the disparity between the earnings of junior and senior people is too great for health and comfort. By comparison, the laboratories of the Atomic Energy Commission are lucky that the Chairman of the Atomic Energy Commission is almost by definition a scientist with roots in research, that the Department of Atomic Energy is constitutionally responsible directly to the Prime Minister and that they are in any case a long way from Delhi. On all the evidence, the most urgent need is that the ministers responsible for research should practise what they preach, and grant the research councils a measure of meaningful autonomy.

The way in which one of the immediate consequences or Dr Shah's suicide has been the mounting of a personal attack on Dr M. S. Swaminathan, the Director-General of the Indian Agricultural Research Council, is at once a sign of how urgent is the need for change and a potential danger to the reputation of Indian science overseas. For Dr Swaminathan is a scientist of the highest reputation, personally responsible for much of the remarkable progress which has been made in Indian agriculture in the past few years. If the inspiration of the Green Revolution has been the development of new strains of wheat and rice in Mexico and the Philippines, its practical application in India has been to a large extent Dr Swaminathan's doing. If now, three months after taking over his new job, he should be pilloried for the long-standing deficiencies of the organization he has inherited and ifas secms to be the case-some of his critics are in effect complaining at his political friends, it is hard to see how the Government of India will in future be able to recruit good men to organize public research. Worse still, it is hard to see how Indian science will earn the credit overseas to which it is entitled. 